\title{
Verification of Effectiveness of Employment Information on Productivity Performance in Japanese Companies
}

\author{
Ryohei Sotome and Masako Takahashi
}

\begin{abstract}
The impact of employment systems on productivity performance is a crucial management issue not limited to labor-intensive enterprises. Japanese companies do not recognize the importance of employment information. In order for executives to understand its importance, this research verifies the effectiveness of employment information on productivity performance in Japanese companies. In addition, influential information categories and indicators with respect to productivity performance are identified. DEA and DEA Malmquist Indices are applied so as to define productivity performance. As a result, the companies, which actively engage in disclosing employment information, tend to be productive. Furthermore, the model including quantitative indicators calculated from employment information is more explanatory than the model including solely financial indicators. In particular, turnover rate, average length of service and average annual salary are the most influential indicators. Contrary to the philosophy of long-term employment, higher liquidity is preferred in Japanese companies.
\end{abstract}

Index Terms-DEA, employment information, Japanese employment system, Malmquist index, productivity

\section{INTRODUCTION}

The Japanese economy has been stagnant over last two decades since the bubble economy collapsed in 1991. According to the Cabinet of National Accounts of Japan, the average GDP growth rate of $1991-2011$ is $0.8 \%$ compared to $9.1 \%$ of $1956-1973$ and $4.1 \%$ of $1974-1990$. Japan has problems with a low productivity growth as well as decreasing workforce. Japan Industrial Productivity database shows that TFP (Total Factor Productivity) growth rate of Japan has plunged to $0.5 \%$ of $1990-2006$ compared to $1.6 \%$ of 1970-1990. Therefore it is necessary for the Japanese economy to raise productivity performance to get out of this severe recession.

Compared to Asian countries such as China, South Korea, Taiwan, Singapore and Hong Kong, Japan has much lower TFP growth rate. The United States with higher TFP level has a higher TFP growth rate. Japan needs to revitalize its productivity performance in order to catch up with other countries.

Japanese companies are struggling to maintain their competitive advantages in the global market due to rapid globalization. Emerging countries such as China and India are becoming threats for them as well as South Korea and

Manuscript received November 9, 2013; revised January 8, 2014.

Ryohei Sotome is with the Graduate School of Science and Technology, Keio University, Japan (e-mail: sotome@ae.keio.ac.jp).

Masako Takahashi is with the Faculty of Science and Technology, Keio University, Japan (e-mail:masako@ae.keio.ac.jp). other developed countries. Japanese companies have been forced to make severe cost-cuts. In response to the external changes, they need to improve their productivity performance.

Furthermore, Japan was ranked low in the fields related to employment system according to the Global Competitiveness Ranking published by World Economic Forum 2012. For example, Japan was ranked 134th in hiring and firing practices, 87 th in the ratio of women to men in the labor force.

Japanese management has unique features characterized by lifetime employment and seniority wage system. These systems based on long-term employment were admired during the period of rapid economic growth, in contrast to the meritocratic systems seen especially in American companies. However it is said that they have been no more effective after the economy became mature. Accordingly meritocratic systems such as stock option system have been implemented in several Japanese companies.

Employment systems are important for Japanese companies in order to improve productivity performance. However, the number of Japanese companies disclosing employment information is still limited. Almost one-third of listed companies disclose employment information. Executives do not often recognize the importance of employment information.

Executives need to understand how employment information characterizes productivity performance. The power of employment information needs to be examined. Therefore, this study investigates the effectiveness of employment information on productivity performance in Japanese companies.

\section{PREVIOUS RESEARCH}

There are various types of studies in the field of productivity problems in the Japanese economy. Kwon, Fukao and Kim [1] investigated the impact of R\&D investment on productivity growth and observed its positive effects statistically. Kim, Fukao and Makino [2] examined the structural causes of productivity slowdown. This study proved that the slowdown in productivity after 1990 was caused not by firm turnover but by within-firm effect. The difference between large companies and SMEs in productivity growth rate was observed. Especially independent SMEs have low TFP level and growth rate. Fukao and Kwon [3] identified factors influencing job creation, capital accumulation and TFP growth rate. With respect to TFP growth rate, size, foreign companies, corporate age, export intensity and $R \& D$ intensity were defined as the determining factors. Morikawa [4] empirically 
analyzed the relationship between corporate performance, such as productivity and profitability, and the existence of labor union. Consequently labor unions have positive relations with productivity level and growth rate (Labor productivity, TFP). Morikawa [5] analyzed the relationship between stock option and productivity in Japanese companies by using the panel data. Stock options have a positive effect on productivity. Furthermore the longer period after its implementation raises productivity. Morikawa [6] gave an overview of business restructuring, showing that there are many stable characteristics of Japanese firms concerning restructuring behavior. This study pointed out the reluctance to reduce the number of employees in Japanese companies.

Concerning employment systems, Hamaaki, Hori, Maeda and Murata [7] implied that lifetime employment system and seniority system had been crumbling. The benefits of these employment systems are brought to college degree workers in large companies. The difference in wage among different age groups has been diminishing. Moreover, the number of workers under lifetime employment is decreasing. Ono [8] measured the Japanese lifetime employment. Turnover rate in human resource differs in gender, marital status, corporate size, university degree and part-time. In addition, Japan has the second longest average length of service and has the highest male-to-female ratio among OECD countries. Liquidity is low compared to other counties. Lifetime employment still exists.

There are several previous studies related to productivity performance and employment systems in Japanese companies. However the employment information has not been fully considered regarding productivity performance. Therefore, this study verifies the effectiveness of employment information on productivity performance in Japanese companies.

\section{APPROACH}

This study goes through the following procedure to calculate the productivity performance indices and analyze the relationship between employment information and productivity performance.

\section{A. Calculation of Productivity Performance Indices}

Data Envelopment Analysis (DEA) is used in this study to calculate productivity performance. DEA is a data oriented approach for evaluating the performance of entities called Decision Making Units (DMUs) which convert multiple inputs to multiple outputs. The characteristics of DEA are flexible in choice of multiple inputs and outputs and do not need to assume production function compared to a parametric approach. Furthermore, each DMU can choose the set of the weights that maximize its efficiency relative to other DMUs.

The most basic model is the CCR model with the assumption of Constant Return to Scale. However this assumption is not suitable for the existing Japanese companies. BCC model which assumes Variant Return to Scale (VRS) is used [9], [10].

\section{B. BCC Model}

$$
\max D_{j}=\frac{\sum_{r=1}^{2} u_{r} y_{r j}+u_{0}}{\sum_{i=1}^{3} v_{i} x_{i j}} \leq 1(j=1,2, \ldots, n)
$$

subject to

$$
\frac{\sum_{r=1}^{2} u_{r} y_{r j}+u_{0}}{\sum_{i=1}^{3} v_{i} x_{i j}} \leq 1(j=1,2, \ldots, n)
$$

$u_{r} \geq 0(r=1,2), v_{i} \geq 0(i=1,2,3), u_{0}=$ Constant term

$y_{1}=$ Sales $y_{2}=$ Operating profit

$x_{1}=$ Number of employees

$x_{2}=$ Tangible assets + Intangible asset

+ accumulated depreciation

$x_{3}=$ Operating Expenses - personel expense -depreciation expense

DEA Malmquist Index is used in order to conduct time-series analysis. By extracting from Malmquist Index, Pure Technical Efficiency (PTE) change is calculated and regarded as productivity growth rate with VRS assumption. Malmquist Index is a measurement technique that uses the efficient frontier of the DEA in order to estimate inter-temporal changes in productivity. Malmquist Index $\left(M I_{t, t+1}\right)$ between adjacent periods $(t, t+1)$ is defined as follows;

\section{Malmquist Index Decomposition}

$$
\begin{aligned}
M I_{t, t+1}= & \left\{\frac{D^{t}\left(x_{t+1}, y_{t+1}\right)}{D^{t}\left(x_{t}, y_{t}\right)} \times \frac{D^{t+1}\left(x_{t+1}, y_{t+1}\right)}{D^{t+1}\left(x_{t}, y_{t}\right)}\right\}^{\frac{1}{2}} \\
= & \frac{D^{t+1}\left(x_{t+1}, y_{t+1}\right)}{D^{t}\left(x_{t}, y_{t}\right)} \\
& \times\left\{\frac{D^{t}\left(x_{t+1}, y_{t+1}\right)}{D^{t+1}\left(x_{t+1}, y_{t+1}\right)} \times \frac{D^{t}\left(x_{t}, y_{t}\right)}{D^{t+1}\left(x_{t}, y_{t}\right)}\right\}^{\frac{1}{2}}
\end{aligned}
$$

$D^{t}\left(x_{t}, y_{t}\right)=$ Distance from efficiency frontier at period $t$

In the lower expression (2), the inside of the parentheses represents technological change, the outside indicates technical efficiency change. The technical efficiency change decomposes into scale efficiency change and PTE change (3).

\section{Technical Efficiency Change Decomposition}

Technical Efficiency change $=$

$$
\begin{aligned}
\frac{S_{o}^{t}\left(x^{t}, y^{t}\right)}{S_{o}^{t+1}\left(x^{t+1}, y^{t+1}\right)} & \times \frac{D_{o}^{t+1}\left(x^{t+1}, y^{t+1} \mid \mathrm{VRS}\right)}{D_{o}^{t}\left(x^{t}, y^{t} \mid \mathrm{VRS}\right)} \\
S_{o}(x, y) & =D_{o}(x, y \mid \mathrm{VRS}) / D_{o}(x, y \mid \mathrm{CRS})
\end{aligned}
$$

The first ratio is the change in scale efficiency and the second indicates PTE change measured relative to the variant return to scale, which is defined as productivity growth rate in this study.

\section{E. Analytical Process}

In order to verify the effectiveness of employment information on productivity performance in Japanese companies, this research uses the following procedure.

\section{F. Effect of Presence of Employment Information Disclosure}

This study uses Mann-Whitney $U$ test which is a non-parametric statistical approach in order to examine the difference between disclosure group and non-disclosure 
group of the companies with respect to productivity performance.

\section{G. Relationship with Employment Information Content}

This research compares the model including employment information with the reference model* including mostly financial indicators.

*As a reference model, determining factors of productivity performance are used as variables [3]. However,

1) A logarithm of VRS productivity corresponded to PTE change is used.

2) A logarithm of the size in operating activities is used instead of sales.

3) Shareholder composition is used rather than foreign company dummy.

4) Overseas investment balance/ sales is excluded.

5) The above four points are modified.

The regression models including employment information are defined as follows.

Employment model $C$ : Dependent variables are category scores of employment information disclosed in addition to variables of the reference model (Table I A). The calculation procedure for each category score is the following;

1) Evaluate each question in the survey. (Presence 1 or absence 0 of information disclosure)

2) Weight each score by disclosure rate of each question.

3) Sum up the scores in the same category.

TABLE I A): INDICATORS IN EMPLOYMENT MODEL C

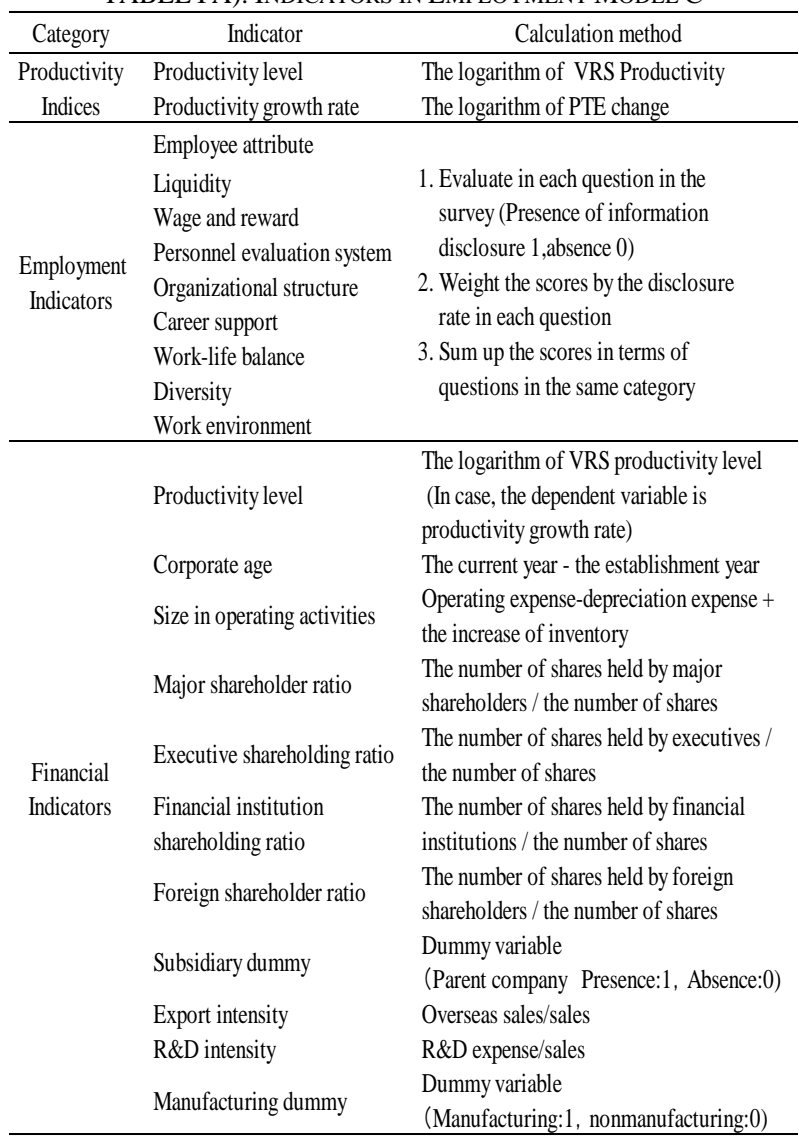

Employment model $N$ : Dependent variables are employment indicators derived from employment information disclosed, through which the conditions of management can be evaluated. The employment information is obtained from the categories of employee attribute, liquidity, wage and reward (Table I B).

TABLE I B): INDICATORS IN EMPLOYMENT MODEL N

\begin{tabular}{|c|c|c|}
\hline Category & Indicator & Calculation method \\
\hline $\begin{array}{l}\text { Productivity } \\
\text { Indices }\end{array}$ & $\begin{array}{l}\text { Productivity level } \\
\text { Productivity growth rate }\end{array}$ & $\begin{array}{l}\text { The logarithm of VRS Productivity } \\
\text { The logarithm of PTE change }\end{array}$ \\
\hline \multirow{15}{*}{$\begin{array}{l}\text { Employment } \\
\text { Indicators }\end{array}$} & Average age & Average age \\
\hline & Age difference in gender & Male average age - Female average age \\
\hline & Age variability & Standard deviation of age distribution \\
\hline & $\begin{array}{l}\text { Temporary worker } \\
\text { percentage }\end{array}$ & $\begin{array}{l}\text { The number of temporary workers / } \\
\text { the number of employees }\end{array}$ \\
\hline & Employee turnover rate & $\begin{array}{l}\text { The number of employees leaving their jobs / } \\
\text { the number of employees, the beginning of year }\end{array}$ \\
\hline & $\begin{array}{l}\text { New employee retention } \\
\text { rate }\end{array}$ & $\begin{array}{l}\text { The number of new employees retained after } \\
3 \text { years passed / The number of new employees }\end{array}$ \\
\hline & Average length of service & Average length of service \\
\hline & Manager percentage & $\begin{array}{l}\text { The number of managers / } \\
\text { the number of employees, the end of year }\end{array}$ \\
\hline & $\begin{array}{l}\text { Female employee } \\
\text { percentage }\end{array}$ & $\begin{array}{l}\text { The number of female employees / } \\
\text { the number of employees, the end of year }\end{array}$ \\
\hline & Female manager ratio & $\begin{array}{l}\text { The number of female managers / } \\
\text { the number of managers }\end{array}$ \\
\hline & Female executive ratio & $\begin{array}{l}\text { The number of female executives / } \\
\text { the number of executives }\end{array}$ \\
\hline & New graduate percentage & $\begin{array}{l}\text { The number of new graduates hired / } \\
\text { the number of employees, the end of year }\end{array}$ \\
\hline & Mid-career percentage & $\begin{array}{l}\text { The number of mid-careers hired / } \\
\text { the number of employees, the end of year }\end{array}$ \\
\hline & Average annual salary & Average annual salary \\
\hline & Stock option dummy & Dummy variable (Presence: 1, Absence:0) \\
\hline \multirow{11}{*}{$\begin{array}{l}\text { Financial } \\
\text { Indicators }\end{array}$} & Productivity level & $\begin{array}{l}\text { The logarithm of VRS productivity level } \\
\text { (In case, dependent variable is productivity } \\
\text { growth rate) }\end{array}$ \\
\hline & Corporate age & The current year - the establishment year \\
\hline & Size in operating activities & $\begin{array}{l}\text { Operating expense-depreciation expense } \\
+ \text { the increase of inventory }\end{array}$ \\
\hline & Major shareholder ratio & $\begin{array}{l}\text { The number of shares held by major } \\
\text { shareholders / the number of shares }\end{array}$ \\
\hline & $\begin{array}{l}\text { Executive shareholding } \\
\text { ratio }\end{array}$ & $\begin{array}{l}\text { The number of shares held by executives / } \\
\text { the number of shares }\end{array}$ \\
\hline & $\begin{array}{l}\text { Financial institution } \\
\text { shareholding ratio }\end{array}$ & $\begin{array}{l}\text { The number of shares held by financial } \\
\text { institutions / the number of shares }\end{array}$ \\
\hline & Foreign shareholder ratio & $\begin{array}{l}\text { The number of shares held by foreign } \\
\text { shareholders / the number of shares }\end{array}$ \\
\hline & Subsidiary dummy & $\begin{array}{l}\text { Dummy variable } \\
\text { (Parent company Presence: } 1 \text {, Absence:0) }\end{array}$ \\
\hline & Export intensity & Overseas sales/sales \\
\hline & $R \& D$ intensity & R\&D expense/sales \\
\hline & Manufacturing dummy & $\begin{array}{l}\text { Dummy variable } \\
\text { (Manufacturing:1, nonmanufacturing:0) }\end{array}$ \\
\hline
\end{tabular}

These two models are examined in comparison with the reference model in terms of explanatory power. Afterward, the influential indicators in employment model $\mathrm{N}$ are identified.

\section{SAMPLE COMPANIES}

The data between the analytical periods 2006-2012 for the productivity performance indices as well as the financial indices is collected by means of Nikkei NEEDS database. In addition, the employment data which is available solely in 2006-2011 is gathered from CSR KigyoSoran (CSR Survey of Japanese corporations [11]) 2008 2013. By excluding A-D groups of enterprises for this research, the sample companies are obtained (Table II).

1) Companies which lack the financial or employment data

2) Companies in finance and insurance industry defined by

Nikkei Business Classification

3) Holding companies

4) Outliers

Chemicals, machinery, electric machinery, construction, trading companies, retail and services are the majority of the sample companies. Regarding disclosure rate, manufacturing 
sectors have higher rate compared to non-manufacturing sectors. Electric machinery, automobile \& auto-parts, precision instrument industries have high disclosure rate with enough sample. These are major industries in Japan.

\begin{tabular}{|c|c|c|c|c|}
\hline \multirow[b]{2}{*}{ Category } & \multicolumn{3}{|c|}{ Number of companies } & \multirow[b]{2}{*}{$\begin{array}{l}\text { Disclosure } \\
\text { rate }\end{array}$} \\
\hline & All & $\begin{array}{l}\text { Disclosure } \\
\text { (Emp C) }\end{array}$ & $\begin{array}{c}\text { Disclosure } \\
\text { (Emp N) }\end{array}$ & \\
\hline Foods & 106 & 47 & 32 & 0.44 \\
\hline Textiles \& Apparel & 43 & 20 & 9 & 0.47 \\
\hline Pulp \& Paper & 21 & 8 & 8 & 0.38 \\
\hline Chemicals & 186 & 80 & 49 & 0.43 \\
\hline Pharmaceuticals & 42 & 19 & 9 & 0.45 \\
\hline Petroleum & 10 & 2 & 0 & 0.20 \\
\hline Rubber & 20 & 12 & 12 & 0.60 \\
\hline Glass \& Ceramics & 58 & 17 & 8 & 0.29 \\
\hline Steel & 48 & 16 & 10 & 0.33 \\
\hline Nonferrous Metal & 108 & 35 & 23 & 0.32 \\
\hline Machinery & 215 & 74 & 43 & 0.34 \\
\hline Electric Machinery & 234 & 120 & 80 & 0.51 \\
\hline Shipbuilding & 5 & 1 & 1 & 0.20 \\
\hline Automobile \& Auto parts & 77 & 42 & 31 & 0.55 \\
\hline Transportation Equipment & 13 & 8 & 3 & 0.62 \\
\hline Precision Instruments & 39 & 20 & 15 & 0.51 \\
\hline Other Manufacturing & 106 & 34 & 25 & 0.32 \\
\hline Manufacturing & 1,331 & 555 & 358 & 0.42 \\
\hline Fishery & 9 & 2 & 1 & 0.22 \\
\hline Mining & 5 & 0 & 0 & 0.00 \\
\hline Construction & 152 & 62 & 47 & 0.41 \\
\hline Trading Companies & 308 & 130 & 84 & 0.42 \\
\hline Retail & 192 & 66 & 34 & 0.34 \\
\hline $\begin{array}{l}\text { Banking, Securities, } \\
\text { Insurance and Other } \\
\text { Financial Services }\end{array}$ & Excluded & Excluded & Excluded & Excluded \\
\hline Real Estate & 68 & 27 & 14 & 0.40 \\
\hline Railway \& Bus & 26 & 8 & 5 & 0.31 \\
\hline Land Transport & 28 & 11 & 3 & 0.39 \\
\hline Marine Transport & 16 & 6 & 3 & 0.38 \\
\hline Air Transport & 4 & 1 & 1 & 0.25 \\
\hline Warehousing & 42 & 17 & 12 & 0.40 \\
\hline Communication & 25 & 9 & 6 & 0.36 \\
\hline Electric Power & 11 & 10 & 7 & 0.91 \\
\hline Gas & 13 & 4 & 1 & 0.31 \\
\hline Service & 508 & 164 & 87 & 0.32 \\
\hline Non-manufacturing & 1,407 & 517 & 305 & 0.37 \\
\hline All industries & 2,738 & 1,072 & 663 & 0.39 \\
\hline
\end{tabular}

\section{RESULTS AND CONSIDERATION}

\section{A. Effect of Presence of Employment Information Disclosure}

This part examines the difference of the productivity performance in the presence of employment information disclosure.

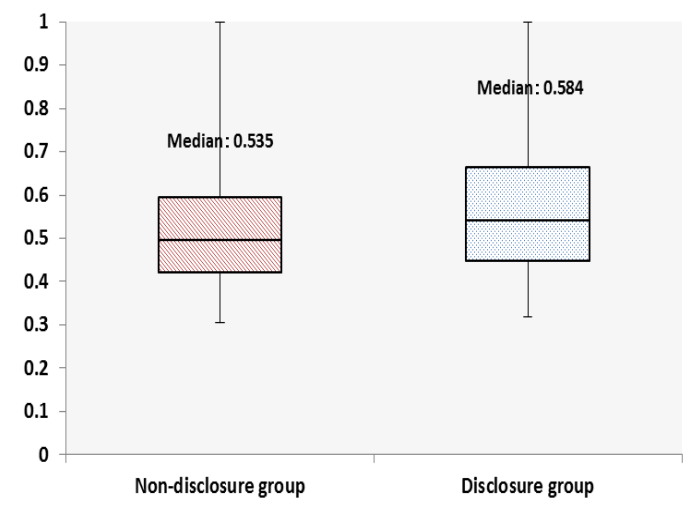

Fig. 1. VRS productivity comparison.

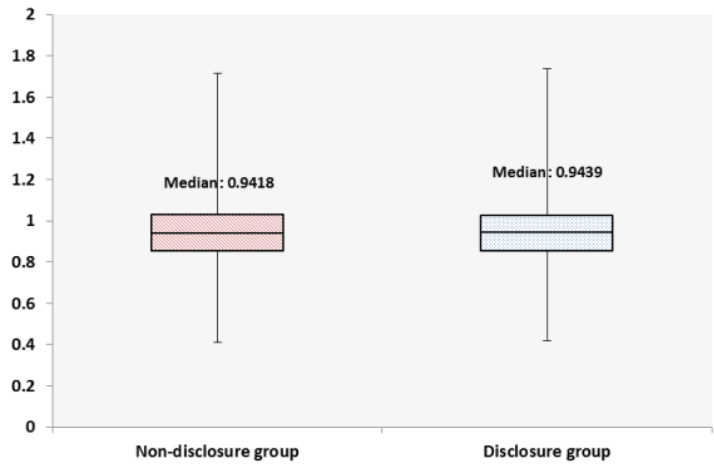

Fig. 2. PTE change comparison.

TABLE III: MANN-WHITNEY U TEST

\begin{tabular}{clr}
\hline \multirow{2}{*}{ VRS } & Standardized test statistics & -7.950 \\
& Asymptotic significance (two-tailed test) & 0.000 \\
& Decision & Rejecting the null hypothesis \\
\hline \multirow{3}{*}{ PTE } & Standardized test statistics & -0.705 \\
& Asymptotic significance (two-tailed test) & 0.481 \\
& Decision & Accepting the null hypothesis \\
\hline
\end{tabular}

Companies that disclose employment information tend to be more productive than non-disclosure companies (Fig. 1). On the other hand, regarding productivity growth rate, there is not a significant difference between these two groups (Fig. 2). In fact, Mann-Whitney $U$ test proves that there is a significant statistical difference in distribution concerning VRS productivity contrary to PTE change (Table III).

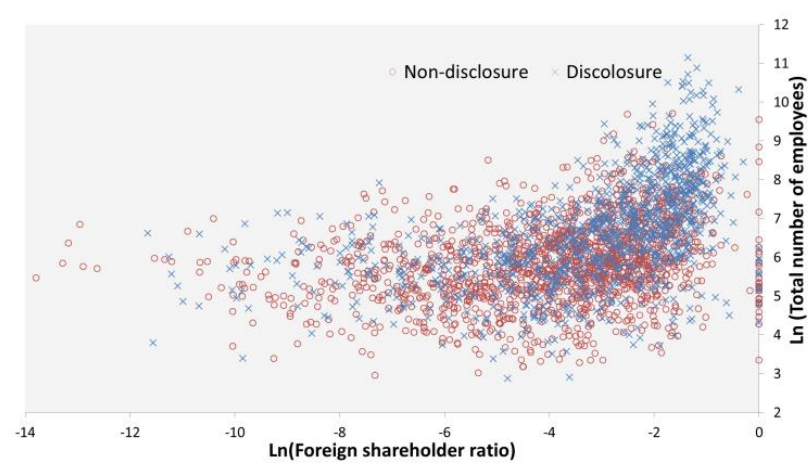

(Foreign shareholder ratio-total number of employees)

Fig. 3. Difference in disclosure.

\begin{tabular}{llc}
\multicolumn{2}{c}{ TABLE IV: MANN-WHITNEY U TEST } \\
\hline \multirow{3}{*}{ Foreign shareholder ratio } & Standardized test statistics & -11.379 \\
& Asymptotic significance (two-tailed test) & 0.000 \\
& Decision & Rejecting the null hypothesis \\
\hline \multirow{3}{*}{ Total number of employees } & Standardized test statistics & -14.187 \\
& Asymptotic significance (two-tailed test) & 0.000 \\
& Decision & Rejecting the null hypothesis \\
\hline
\end{tabular}

Companies with higher foreign shareholder ratio and larger number of employees tend to disclose employment information (Fig. 3, Table IV). It indicates that the companies with higher foreign shareholder ratio out of necessity disclose more information to the public and the companies with larger human resource have their social responsibility to disclose employment information. Furthermore, it is probable that the disclosure companies can attract more foreign shareholders who are seeking the investment opportunities in foreign countries.

\section{B. Relationship with Employment Information Content}

The employment model $\mathrm{C}$ including category scores of 
employment information disclosed is compared with the reference model including determining factors of productivity performance [3] in terms of co-efficient of determination (Table V). The significance level is defined as $*=5 \% * *=1 \% * * *=0.1 \%$. The same shall apply hereafter.

\begin{tabular}{llcc}
\multicolumn{4}{c}{ TABLE V: COMPARISON IN CO-EFFICIENT OF DETERMINATION } \\
\hline \multirow{2}{*}{ VRS productivity } & Reference & Employment C \\
& F-value & $156.40^{* * *}$ & $198.19^{* * * *}$ \\
& Adjusted R-square & $0.592^{* * *}$ & 0.596 \\
\hline \multirow{2}{*}{ PTE change } & F-value & $7.52^{* * *}$ & $9.54^{* * * *}$ \\
& Adjusted R-square & $0.081^{*}$ & 0.111 \\
\hline
\end{tabular}

Table V shows that the employment model C improves the coefficient of determination. However, there is no significant difference between these two models. It indicates that categories of employment information disclosed do not involve in characterizing productive companies even though productive companies tend to have employment disclosure. However, in terms of VRS productivity level, the categories such as diversity, work environment, wage and reward are statistically significant among the explanatory variables chosen by stepwise regression model (Table VI). Since diversity and work environment are highly correlated, these are separately examined.

TABLE VI: COMPARISON IN CO-EFFICIENT OF DETERMINATION

\begin{tabular}{lcr}
\hline Category & Partial regression coefficient & p-value \\
\hline Employee attribute & & \\
Liquidity & $-0.016^{*}$ & 0.017 \\
Wage and Reward & & \\
Personnel evaluation system & & \\
Organizational structure & & \\
Career support & & \\
Work-life balance & $0.021^{* *}$ & 0.004 \\
Diversity & $\left(0.014^{*}\right)$ & $(0.042)$ \\
Work environment & & \\
\hline
\end{tabular}

Many of the items in diversity and work environment are added to the CSR survey from 2011 and these items have the lowest disclosure rates (Table VII). This result implies those companies that actively disclose employment information tend to be productive. On the other hand, in the field of wage and rewards, a negative relationship is observed.

\section{TABLE VII: DISCLOSURE RATE BY CATEGORY}

\begin{tabular}{lccc}
\hline \multicolumn{1}{c}{ Category } & Average Disclosure rate & Number of items & Added items in 2011 ratio \\
\hline Employee attribute & 0.80 & 8 & 0.13 \\
Liquidity & 0.80 & 8 & 0.00 \\
Wage and Reward & 0.63 & 5 & 0.00 \\
Personnel evaluation syster & 0.59 & 5 & 1.00 \\
Structure & 0.74 & 4 & 0.25 \\
Career support & 0.91 & 2 & 0.00 \\
Work-life balance & 0.77 & 23 & 0.17 \\
Diversity & 0.41 & 14 & 0.57 \\
Work environment & 0.46 & 10 & 0.90 \\
\hline
\end{tabular}

In the categories, employee attribute, liquidity, wage and reward, there are several quantitative items. This study firstly compares the employment model $\mathrm{N}$ including employment indicators using those items with the reference model through the different analysis $I-\mathrm{V}^{1}$.

${ }^{1}$ I: Average employment and financial data 2006-2011, Average productivity index 2006-2012, Productivity growth rate 2006-2012

II: Average employment and financial data 2006-2011, Average productivity index 2009-2011, Productivity growth rate 2009-2011
Secondly, the indicators selected with stepwise regression are investigated by means of the influential score. Tables 8-1, 8-2 show the comparison between two models in terms of co-efficient of determination.

\section{Productivity}

TABLE VIII A): COMPARISON IN CO-EFFICIENT OF DETERMINATION (VRS

\begin{tabular}{|c|c|c|c|c|}
\hline \multicolumn{5}{|c|}{ PRODUCTIVITY) } \\
\hline & & Reference model & & Employment model $\mathrm{N}$ \\
\hline \multirow{6}{*}{ All sectors } & I & $0.53\left(74.6^{* * *}\right)$ & $<$ & $0.59\left(58.0^{* * * *}\right)$ \\
\hline & II & $0.52\left(73.45^{* * * *}\right)$ & $<$ & $0.58\left(66.1^{* * * *}\right)$ \\
\hline & III & $0.53\left(61.7^{* * * *}\right)$ & $<$ & $0.61\left(52.7^{* * *}\right)$ \\
\hline & IV & $0.49\left(53.3^{* * *}\right)$ & $<$ & $0.58\left(40.1^{* * *}\right)$ \\
\hline & $\mathrm{V}$ & $0.51\left(57.0^{* * * *}\right)$ & $<$ & $0.58\left(49.5^{* * *}\right)$ \\
\hline & Average & 0.52 & $<$ & 0.59 \\
\hline \multirow{6}{*}{ Manufacturing } & I & $0.47\left(36.00^{* * * *}\right)$ & $<$ & $0.60\left(30.42^{* * * *}\right)$ \\
\hline & II & $0.32\left(19.51^{* * * *}\right)$ & $<$ & $0.47\left(21.98^{* * * *}\right)$ \\
\hline & III & $0.42\left(25.62^{* * * *}\right)$ & $<$ & $0.53\left(25.35^{* * * *}\right)$ \\
\hline & IV & $0.46\left(29.90^{* * * *}\right)$ & $<$ & $0.56\left(39.11^{* * * *}\right)$ \\
\hline & V & $0.28\left(13.91^{* * * *}\right)$ & $<$ & $0.40\left(14.11^{* * * *}\right)$ \\
\hline & Average & 0.39 & $<$ & 0.51 \\
\hline \multirow{6}{*}{ Non-manufacturing } & I & $0.35\left(19.80^{* * * *}\right)$ & $<$ & $0.45\left(19.62^{* * * *}\right)$ \\
\hline & II & $0.30\left(16.01^{* * * *}\right)$ & $<$ & $0.42\left(17.28^{* * * *}\right)$ \\
\hline & III & $0.38\left(15.30^{* * * *}\right)$ & $<$ & $0.49\left(16.04^{* * * *}\right)$ \\
\hline & IV & $0.33\left(12.39^{* * * *}\right)$ & $<$ & $0.45\left(12.37^{* * * *}\right)$ \\
\hline & V & $0.37\left(21.90^{* * * *}\right)$ & $<$ & $0.46\left(25.09^{* * * *}\right)$ \\
\hline & Average & 0.35 & $<$ & 0.45 \\
\hline
\end{tabular}

TABLE VIII B): COMPARISON IN CO-EFFICIENT OF DETERMINATION (PTE

\begin{tabular}{|c|c|c|c|c|}
\hline \multicolumn{5}{|c|}{ CHANGE) } \\
\hline & & Reference model & & Employment model $\mathrm{N}$ \\
\hline \multirow{6}{*}{ All sectors } & I & $0.26\left(21.9^{* * *}\right)$ & $<$ & $0.28\left(29.1^{* * *}\right)$ \\
\hline & II & $0.27\left(23.3^{* * * *}\right)$ & $<$ & $0.28\left(33.4^{* * * *}\right)$ \\
\hline & III & $0.25\left(16.8^{* * *}\right)$ & $<$ & $0.27\left(16.3^{* * *}\right)$ \\
\hline & IV & $0.17\left(10.8^{* * * *}\right)$ & $<$ & $0.22\left(11.5^{* * * *}\right)$ \\
\hline & $\mathrm{V}$ & $0.29\left(20.4^{* * * *}\right)$ & $<$ & $0.30\left(23.9^{* * * *}\right)$ \\
\hline & Average & 0.25 & $<$ & 0.27 \\
\hline \multirow{6}{*}{ Manufacturing } & I & $0.24\left(12.27^{* * * *}\right)$ & $<$ & $0.32\left(10.72^{* * * *}\right)$ \\
\hline & II & $0.18\left(8.95^{* * *}\right)$ & $<$ & $0.26\left(12.30^{* * * *}\right)$ \\
\hline & III & $0.21\left(8.79^{* * *}\right)$ & $<$ & $0.28\left(8.72^{* * *}\right)$ \\
\hline & IV & $0.46\left(26.26^{* * * *}\right)$ & $<$ & $0.48\left(28.45^{* * * *}\right)$ \\
\hline & $\mathrm{V}$ & $0.16\left(6.68^{* * * *}\right)$ & $<$ & $0.23\left(10.78^{* * * *}\right)$ \\
\hline & Average & 0.25 & $<$ & 0.31 \\
\hline \multirow{6}{*}{ Non-manufacturing } & I & $0.17\left(7.69^{* * * *}\right)$ & $<$ & $0.20\left(12.00^{* * * *}\right)$ \\
\hline & II & $0.25\left(11.36^{* * *}\right)$ & $<$ & $0.27\left(17.80^{* * *}\right)$ \\
\hline & III & $0.17\left(5.64^{* * *}\right)$ & $<$ & $0.19\left(18.81^{* * * *}\right)$ \\
\hline & IV & $0.12\left(4.15^{* * *}\right)$ & $<$ & $0.27\left(7.70^{* * *}\right)$ \\
\hline & V & $0.27\left(9.65^{* * *}\right)$ & $<$ & $0.31\left(21.60^{* * * *}\right)$ \\
\hline & Average & 0.20 & $<$ & 0.25 \\
\hline
\end{tabular}

The employment model $\mathrm{N}$ improves co-efficient of determination in terms of VRS productivity level (Table VIII A). Both of the models are the most explanatory by including all industries. When the companies are divided into manufacturing and non-manufacturing, the employment model $\mathrm{N}$ improves the explanatory power effectively.

\section{Productivity Growth Rate}

Consistently the employment model $\mathrm{N}$ improves co-efficient of determination with respect to PTE change (Table VIII B). However both of the models have lower

III: Average employment and financial data 2006-2008, Average productivity index 2006-2012, Productivity growth rate 2006-2012

IV: Average employment and financial data 2006-2008, Average productivity index 2006-2008, Productivity growth rate 2006-2008

V: Average employment and financial data 2006-2008, Average productivity index 2009-2011, Productivity growth rate 2009-2011 
explanatory power in PTE change than VRS productivity. This result implies that it is troublesome to identify companies with higher productivity growth rate with these two models compared to productivity level due to the yearly frequent change of productivity growth rate.

Tables IX A) and Table IX B) show average partial regression coefficient (PRC) and the influential score (IS) for each indicator. The definition of the influential score is that the number of the partial regression coefficients with $5 \%$ significance level is taken into account only if plus or minus sign is consistent among all analysis I-V.

TABLE IX A): PARTIAL REGRESSION COEFFICIENT AND INFLUENTIAL SCORES (VRS PRODUCTIVITY)

\begin{tabular}{llrrrrr}
\hline \multirow{2}{*}{\multicolumn{1}{c}{ Indicators }} & \multicolumn{6}{c}{ VRS Productivity } \\
\cline { 2 - 7 } & All industries & \multicolumn{1}{c}{ Manufacturing } & Non-manufacturing \\
\cline { 2 - 7 } Average age & IS & PRC & IS & PRC & IS & PRC \\
Age difference in gender & & & & & & \\
Age variability & & & +3 & 0.009 & & \\
Temporary worker percentage & & & & & & \\
Employee turnover rate & +5 & 0.025 & & & +3 & 0.036 \\
New employee retention rate & +3 & 0.018 & & & +3 & 0.036 \\
Average length of service & -5 & -0.039 & -3 & -0.018 & -2 & -0.046 \\
Manager percentage & +1 & 0.011 & & & +4 & 0.024 \\
Female employee percentage & +5 & 0.019 & +2 & 0.011 & +3 & 0.031 \\
Female manager ratio & -1 & -0.012 & +3 & 0.013 & -1 & -0.023 \\
Female executive ratio & & & +1 & 0.008 & -1 & -0.020 \\
New graduate percentage & & & +2 & 0.011 & & \\
Mid-career percentage & & & & & & \\
Average annual salary & +5 & 0.049 & +5 & 0.045 & +5 & 0.058 \\
Stock option dummy & -2 & -0.010 & -2 & -0.008 & & \\
Corporate age & -5 & -0.019 & -3 & -0.011 & -3 & -0.030 \\
Size in operating activities & +5 & 0.107 & +5 & 0.053 & +5 & 0.094 \\
Major shareholder ratio & & & -3 & -0.010 & & \\
Executive shareholding ratio & +3 & 0.016 & +4 & 0.011 & +2 & 0.026 \\
Financial institution shareholding ratio & -5 & -0.018 & -2 & -0.014 & -3 & -0.028 \\
Foreign shareholder ratio & +5 & 0.024 & & & +5 & 0.033 \\
Subsidiary dummy & & & -1 & -0.010 & & \\
Export intensity & +1 & 0.010 & & & +1 & 0.016 \\
R\&D intensity & & & & & & \\
Manufacturing dummy & -5 & -0.043 & & & & \\
\hline & & & & & &
\end{tabular}

TABLE IX B): PARTIAL REGRESSION COEFFICIENT AND INFLUENTIAL SCORES (PTE CHANGE)

\begin{tabular}{|c|c|c|c|c|c|c|}
\hline \multirow{3}{*}{ Indicators } & \multicolumn{6}{|c|}{ PTE change } \\
\hline & \multicolumn{2}{|c|}{ All industries } & \multicolumn{2}{|c|}{ Manufacturing } & \multicolumn{2}{|c|}{ Non-manufacturing } \\
\hline & IS & PRC & IS & PRC & IS & PRC \\
\hline Average age & & & +4 & 0.027 & & \\
\hline Age difference in gender & -2 & -0.010 & & & & \\
\hline Age variability & & & -2 & -0.010 & +2 & 0.016 \\
\hline \multicolumn{7}{|l|}{ Temporary worker percentage } \\
\hline \multicolumn{7}{|l|}{ Employee turnover rate } \\
\hline New employee retention rate & -1 & -0.009 & & & & \\
\hline Average length of service & -2 & -0.003 & & & & \\
\hline Manager percentage & -1 & -0.010 & & & -1 & -0.012 \\
\hline Female employee percentage & -1 & -0.011 & -1 & -0.009 & -1 & -0.004 \\
\hline Female manager ratio & +2 & 0.017 & -1 & -0.009 & +1 & 0.020 \\
\hline \multicolumn{7}{|l|}{ Female executive ratio } \\
\hline New graduate percentage & & & +2 & 0.019 & & \\
\hline \multicolumn{7}{|l|}{ Mid-career percentage } \\
\hline Average annual salary & & & -1 & -0.015 & & \\
\hline Stock option dummy & & & & & +1 & 0.011 \\
\hline Productivity level & +4 & 0.047 & +5 & 0.022 & +4 & 0.040 \\
\hline \multicolumn{7}{|l|}{ Corporate age } \\
\hline Size in operating activities & +5 & 0.030 & & & +5 & 0.026 \\
\hline \multicolumn{7}{|l|}{ Major shareholder ratio } \\
\hline Executive shareholding ratio & & & -2 & -0.013 & & \\
\hline Financial institution shareholding ratio & & & -2 & -0.013 & & \\
\hline Foreign shareholder ratio & & & -2 & -0.023 & & \\
\hline \multicolumn{7}{|l|}{ Subsidiary dummy } \\
\hline Export intensity & & & +2 & 0.010 & & \\
\hline R\&D intensity & +2 & 0.012 & -1 & -0.015 & +1 & 0.014 \\
\hline Manufacturing dummy & +4 & 0.024 & & & & \\
\hline
\end{tabular}

\section{E. Productivity}

1) Liquidity of human resource: In firing practices, a positive effect of turnover rate and a negative effect of average length of service are strongly observed.
Non-manufacturing sectors experience strong effects from these liquidity indicators. On the other hand, these negative effects are not clearly observed in manufacturing sectors. This implies that manufacturing sectors need to accumulate employees' knowledge and skills in the organizations. Concerning retention rate of new employees, a positive effect is clearly observed in all sectors and non-manufacturing sectors. This implies the companies need to retain new employees in order to avoid loss of hiring costs at the beginning. In hiring practices, a positive effect of new graduate percentage is recognized in manufacturing sectors, because long-term employees are needed.

2) Opportunities for female employees: The percentage of female employees and the female-to-male management ratio have observable effects on productivity level. The percentage of female employees has a positive effect on productivity level. It is likely that female employees have different strengths and roles from male employees so that they cover the weaknesses of each other. On the other hand, the female-to-male management ratio has a negative effect on productivity. This implies that productive companies might be still male-dominated in promotion. Otherwise, female employees are less motivated because it would be more difficult for them to get a promotion.

3) Structure: The percentage of managers has a positive effect on productivity level. It implies that the experienced managers' knowledge and skills contribute to productivity level. The hierarchical structure of the Japanese companies might affect positively productivity level. In particular, Non-manufacturing sectors experience a strong effect from percentage of managers.

4) Salary and reward: Average annual salary and stock options are recognized as influencing factors. The productive companies have higher average annual salaries. On the other hand, the companies with a stock option system tend to be less productive, particularly in manufacturing sectors. Stock options which are relatively new in Japanese companies have not been successful. However, the result is not consistent with previous research [5]. The inconsistency might attribute to the difference in methodology between TFP and DEA or the difference in the sample companies analyzed. This research conducted the analysis on listed companies which are relatively large in size contrary to the previous study which included unlisted companies.

\section{F. Productivity Growth Rate}

1) Liquidity of human resources: By looking at firing practices, a negative effect in average length of service is observed. This result is similar to the result in VRS productivity level. In Japanese companies, longer average length of service time is one of the factors which lead to lower productivity growth rate as well as productivity level. This indicates their lifetime employment systems have failed to increase productivity level. In hiring practices, a positive effect of new graduate percentage is identified in manufacturing sectors. New graduates are important for Japanese manufacturing companies with respect to productivity 
growth as well as productivity level.

2) Opportunities for female employees: The higher the female-to-male management ratio is, the more pleasant productivity growth rate is likely to be delivered. Even though companies with higher female-to-male management ratio are unproductive, this ratio is one of the key elements for their productivity growth. However there is a difference in the results between manufacturing and non-manufacturing.

\section{CONCLUSION}

This study verified the effectiveness of employment information on productivity performance in Japanese companies by using statistical methods. According to the results, the companies disclosing employment information are more productive than non-disclosure companies. In addition, compared to the reference model based on determining factors for productivity performance [3], the proposed model with information category scores enhance explanatory power. Categories such as diversity, work environment, wage and reward are statistically significant. Most of the items in diversity and work environment have been added to the survey from 2011 so that the disclosure rates are the lowest. This result implies the companies which actively disclose employment information tend to be more productive. Furthermore, the model, which includes employment indicators calculated by utilizing basically quantitative employment information, is more explanatory than the reference model. The influential indicators are also identified with respect to productivity performance.

Contrary to the philosophy of Japanese management, the liquidity of employment systems in Japanese companies can have a positive impact on productivity level. In addition, the companies with stock option systems and more promotion opportunities for female employees tend to have low productivity level. With respect to productivity performance, up to now these new initiatives have not been successful. Furthermore, the result implies that the employment systems have a different impact on productivity performance in manufacturing sectors and non-manufacturing sectors respectively. For example, higher liquidity in human resource is needed more in non-manufacturing sectors than manufacturing sectors. It implies that manufacturing sectors need employees' knowledge and skills within the firms.

Executives in Japanese companies can fix their corporate information system in order to utilize their employment information effectively. Furthermore, they can refer to the employment information categories related to liquidity in human resource as well as wage and reward. Moreover they need to understand that the new initiatives, seen as stock option systems and promotion opportunities for female employees, have not been successful.

\section{FUTURE WORK}

This research has limitations in the employment information disclosed. It is possible that an industrial analysis is conducted in order to clarify the effectiveness of employment information more precisely. Furthermore, productivity growth rate is not as well explained by the employment model as productivity level due to the volatility of the external factors. It is necessary to use a more valid productivity measurement technique which can exclude external shocks compared to DEA Malmquist Index.

\section{ACKNOWLEDGMENT}

The authors thank the anonymous reviewers whose constructive comments and evaluation improved the quality of this article.

\section{REFERENCES}

[1] H. U. Kwon, K. Fukao, and Y. Kim, "R\&D and productivity growth: An empirical analysis of firm-level data," Global COE Hi-Stat Discussion Paper Series 003, 2008.

[2] Y. Kim, K. Fukao and T. Makino, "The structural cause of lost two decades," RIETI Policy Discussion Paper Series 10-P-004, in Japanese, 2010.

[3] K. Fukao and H. U. Kwon, "Where is the source of Japanese economic growth: Empirical analysis based on micro data," RIETI Policy Discussion Paper Series 11-J-045, in Japanese, 2011.

[4] M. Morikawa, "Japanese labor union and productivity-An empirical analysis of firm-level data," RIETI Discussion Paper Series 08-J-030, in Japanese, 2008.

[5] M. Morikawa, "Stock option and Productivity," RIETI Policy Discussion Paper Series 12-J-002, in Japanese, 2012.

[6] M. Morikawa, "Business restructuring of japanese firms structural changes during the 'lost decades'," RIETI Policy Discussion Paper Series 13-E-083, 2013

[7] J. Hamaaki, M. Hori, S. Maeda, and K. Murata, "Changes in the Japanese Employment System in the Two Lost Decades," New ESRI Working Paper No.18, 2012.

[8] H. Ono, "Lifetime employment in Japan: Concepts and measurements," Journal of The Japanese and International Economies, vol. 24, pp. 1-27, 2010.

[9] W. W. Cooper, L. M. Seiford and J. Zhu, Handbook on Data Envelopment Analysis, 2nd ed Springer, 2011, ch2 and ch5.

[10] T. Sueyoshi, DEA-Data Envelopment Analysis, Asakura Publishing Co, Ltd., in Japanese, 2001, ch3 and ch7.

[11] CSR Kigyo Soran, 2008-2013 versions, Toyo keizai Inc.

[12] K. Ito, M. Jung, Y. G. Kim, and T. Yuana, "A comparative analysis of productivity growth and productivity dispersion: Microeconomic evidence based on listed firms from Japan, Korea, and China," Working Paper Series No 259, Columbia Business School, Center on Japanese Economy and Business, 2008.

[13] J. Benson, "Japanese management, enterprise unions and company performance," Industrial Relations Journal, vol. 37, no. 3, pp. 242-258, 2006 .

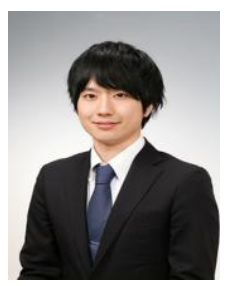

Ryohei Sotome is a postgraduate in center for open systems management, school of science for open and environmental systems at Keio University, Japan. Currently he is also a double degree student in management engineering at Politecnico di Milano, Italy. He received bachelor's degree in Administration Engineering at Keio University.

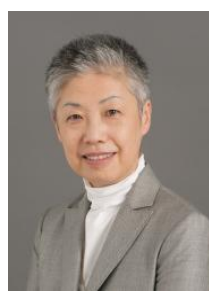

Masako Takahashi is an associate professor in the Department of Administration Engineering, Faculty of Science and Technology at Keio University, Japan. She received her doctor of philosophy in social system engineering from Keio University. She has published various articles and presented at national and international conferences on management administration. Her recent research focuses on sustainable management and accounting. 